\title{
The effects of Sutaehwan-Gami on menopausal symptoms induced by ovariectomy in rats
}

\author{
Dong-II Kim', Min Sun Choi ${ }^{1}$, Sok Cheon Pak², Seung-bok Lee ${ }^{3^{*}}$ and Songhee Jeon ${ }^{4 *}$
}

\begin{abstract}
Background: This study was undertaken to evaluate the beneficial effects of a modified prescription of Sutaehwan named Sutaehwan-Gami (SG), created by adding Rhizoma dioscoreae and Carthami semen to Sutaehwan, on menopausal symptoms.

Methods: To evaluate the estrogenic effect of SG, we first examined estrogen receptor (ER) activation by SG treatment in breast adenocarcinoma cells and confirmed the estrogenic effect of SG in vivo ovariectomized rats. The animals were randomized into four groups: Sham operated group (Sham), saline treated ovariectomized group $(\mathrm{OVX})$, SG treated group (SG) and raloxifene treated group (RLX). Animals were provided with SG at a dose of 500 $\mathrm{mg} / \mathrm{kg}$ bw/day and RLX at a dose of $5.4 \mathrm{mg} / \mathrm{kg}$ bw/day with standard rat pellets for 3 months.
\end{abstract}

Results: SG significantly increased ERa phosphorylation, and its downstream effectors, extracellular signal-regulated kinase (ERK) and protein kinase B (Akt) phosphorylation in breast adenocarcinoma cells. Treatment with SG reversed ovariectomy-induced uterine weight reduction and weight gain. Decreases in the levels of GOT and GPT were observed in the SG group. The significantly reduced $\mathrm{E}_{2} \beta$ level in OVX rats was raised by treatment with SG. Moreover, SG significantly increased the phosphorylation levels of ERK and Akt in the uterus.

Conclusion: Taken together, these data indicate that SG has phytoestrogen-like properties through ERK and Akt activation, implying that it could be protective and beneficial for the management of menopausal symptoms.

Keywords: Sutaehwan-Gami, Menopause, Ovariectomy, Uterus, Estrogen receptor, ERK, Akt

\section{Background}

Menopause is an important physiological event, with the cessation of menstruation indicating the end of a woman's reproductive lifespan. Women in menopausal transition experience a variety of symptoms such as hot flashes, sweating, anxiety, depression, mood swings, sleep disorders, vaginal dryness and joint pain; all of these symptoms are due to the cessation of ovarian estrogen production [1]. The major source of estrogen after menopause is through the conversion of adrenal androgen to estrogen by the enzyme aromatase in the peripheral tissues, but estrogen is maintained at a very low level due to aromatase inhibitors [2].

Estrogen plays multiple biological functions. It is required for the development and maintenance of reproductive

\footnotetext{
* Correspondence: sstarcosmos@hanmail.net; jsong0304@dongguk.edu

${ }^{3}$ SungSung Traditional Korean Medicine Clinic, Yongdam-ro 115, Yeonsu-gu, Incheon 406-818, Republic of Korea

${ }^{4}$ Dongguk University Research Institute of Biotechnology, Dongguk University,

27-3, Phildong 3, Joong-gu, Seoul, Korea 100-715

Full list of author information is available at the end of the article
}

tissues. Estrogen also controls energy homeostasis, core body temperature, bone remodeling and neuroprotection. Estrogen exerts its effects via the known estrogen receptors of ER $\alpha$ and ER $\beta$ by either nuclear- or membrane-mediated signaling mechanism depending on its target tissue [3]. Upon interaction with estrogen, receptors undergo structural changes to promote gene transcription. At the same time, estrogen triggers various protein kinase pathways including the MAPK/ERK and PI3K/Akt pathways [3]. Activation of these signaling cascades leads to the phosphorylation of the AF-1 domain of ER $\alpha$ [4].

Approximately $40 \%$ of women suffering such symptoms seek medical attention from health care providers for the management of menopausal symptoms [5]. Following the report from the Heart and Estrogen/progestin Replacement Study [6] that demonstrated an increased risk of cardiovascular disease and breast cancer among women randomized to hormone therapy and subsequent publication indicating a link between estrogen therapy and endometrial

\section{Biomed Central}

(c) 2012 Kim et al.; licensee BioMed Central Ltd. This is an Open Access article distributed under the terms of the Creative Commons Attribution License (http://creativecommons.org/licenses/by/2.0), which permits unrestricted use, distribution, and reproduction in any medium, provided the original work is properly cited. 
hyperplasia [7], many women refuse to use exogenous hormones and turn to alternative approaches for relief of menopausal symptoms. Herbal mixtures, in decoction or pill form, are one such alternative therapy, and the effects of decoction or pill can be shown after total and final reaction by their constituent compounds when administered to humans.

According to traditional Chinese medicine theory, both menopausal symptoms and threatened abortion are caused by kidney-liver weakness due to a deficiency of essence with accompanying yin-yang imbalance and organ disharmony [8]. Herbal formulas classified as kidney/livertonifying are thus considered suitable for the management of menopausal symptoms. Sutaehwan, which contains the four herbs Semen cuscutae (Dodder seed), Ramulus taxilli (Taxillus twig), Radix dipsaci (Himalayan teasel root) and Colla corii asini (Donkey-hide gelatin), has been used in Korea for the treatment of abortus habitualis including fetal restlessness in the uterus [9]. Semen cuscutae (Dodder seed) has been found to stimulate the reproductive system and reproductive endocrine function in male rats [10]. Moreover, it has shown a phytoestrogenic effect in MCF-7 cells [11]. Ramulus taxilli is traditionally used to tonify the kidneys and nourish the blood [9]. Radix dipsaci is proposed to enhance bone strength and has shown osteoprotective effect in ovariectomized rats [12]. Colla corii asini has long been used for tonifying the liver blood, arresting bleeding and supplementing the kidney yin fluid [9]. Since obesity is a common problem encountered in postmenopausal women as a result of reduced estrogen level [13], our study adopted a modified prescription, Sutaehwan-Gami (SG), that comprised sutaehwan with an addition of Rhizoma dioscoreae (yam), which has shown antiobesity and antihyperlipidemic activities [14,15], and Carthami semen (safflower seed) which is suggested to improve blood circulation to remove blood stasis and promote menstruation, and which exhibited lipid-lowering effects in humans with hyperlipidemia [16]. Our hypothesis is that Sutaehwan-Gami, consisting of six herbs, will strengthen kidney and liver function by nourishing the deficient essence in these organs, and will replace decreased estrogen and prevent the obesity related to menopause.

Our study aimed to determine whether SG has any estrogen-like properties since there have been no previous studies on the benefits of SG for menopausal syndrome. In the present study, ovariectomized rat was used as an animal model for menopause and we investigated the effect of SG on serum, body weight and uterus. We additionally evaluated the phosphorylation of ER $\alpha$ and ERK and Akt in vivo and in vitro.

\section{Methods}

Preparation of Sutaehwan-Gami

Sutaehwan-Gami, a dried decoction of a mixture of six herbs as listed in Table 1, was obtained from the College
Table 1 Prescription of Sutaewhan-Gami

\begin{tabular}{|c|c|c|}
\hline Components & Part used & Amount (g) \\
\hline Semen Cuscutae & Seed & 16 \\
\hline \multicolumn{3}{|l|}{ Cuscuta chinensis L. } \\
\hline Ramulus Taxilli & Stem and branch & 8 \\
\hline \multicolumn{3}{|l|}{ Taxillus chinensis De. (Loranthaceae) } \\
\hline Radix Dipsaci & Root & 8 \\
\hline \multicolumn{3}{|l|}{ Dried root of Dipsacus asperoides } \\
\hline Colla Corii Asini & Donkey hide & 8 \\
\hline \multicolumn{3}{|l|}{ Equus asinus L. (Equidae) } \\
\hline Rhizoma Dioscoreae & Root & 16 \\
\hline \multicolumn{3}{|l|}{ Rhizome of Disoscorea opposita Thunb. } \\
\hline \multicolumn{3}{|l|}{ (Fam. Dioscoreaceae). } \\
\hline Carthami Semen & Flower & 8 \\
\hline \multicolumn{3}{|l|}{ Carthamus tinctorius L. (Asteraceae). } \\
\hline Total amounts & & 64 \\
\hline
\end{tabular}

of Oriental Medicine of Dongguk University. A total of $64 \mathrm{~g}$ of herbs was added to $500 \mathrm{ml}$ of water which was then boiled for $2 \mathrm{hr}$. The decoction was then filtered, lyophilized and stored at $4^{\circ} \mathrm{C}$.

\section{Cell culture}

MCF-7 human breast cancer cells were purchased from the American Type Culture Collection (ATCC, Manassas, VA, USA). Cells were cultured in DMEM (WelGENE, Daegu, Korea) medium supplemented with $10 \%$ fetal bovine serum (WelGENE, Daegu, Korea), 100 unit/ml penicillin (WelGENE, Daegu, Korea) and $100 \mu \mathrm{g} / \mathrm{ml}$ streptomycin (WelGENE, Daegu, Korea). The cells were maintained in a humidified atmosphere containing 5\% $\mathrm{CO}_{2}$ at $37^{\circ} \mathrm{C}$. Cells were then treated with SG at $1 \mu \mathrm{g} / \mathrm{ml}$ for the indicated time $(5,10,30,60$ and $120 \mathrm{~min})$ to measure phosphorylation of ER $\alpha / E R K / A k t$.

\section{Cytotoxicity assay}

Cell viability was determined using 3-[4,5-dimethylthiazol-2-yl]-2,5-diphenyltetrazolium bromide (MTT, Sigma, USA) assay. In brief, MCF-7 cells were seeded on 24well plates at a density of $5 \times 10^{5}$ cells/well and treated with various concentrations $(0.01,0.1,1.0,5.0$ and 10 $\mu \mathrm{g} / \mathrm{ml}$ ) of SG for $48 \mathrm{~h}$. The medium was removed and the cells were incubated with $2 \mathrm{mg} / \mathrm{ml}$ of MTT solution. After incubation for $4 \mathrm{~h}$ at $37^{\circ} \mathrm{C}$ and $5 \% \mathrm{CO}_{2}$, the supernatants were removed and dimethyl sulfoxide (DMSO, Sigma, USA) was added. The reactants were measured in terms of optical density (OD) at $590 \mathrm{~nm}$ with a microplate reader (UV max, Molecular Devices, USA). The optical densities were converted into percentages using the following formula: 
Cell viability $(\%)=$ OD sample/OD negative control $\times$ 100. Negative control cells were treated with complete DMEM alone.

\section{Western blotting analysis}

Thirty micrograms of cell lysates were electrophoresed in SDS-polyacrylamide gels (SDS-PAGE) and transferred to nitrocellulose membranes, which were then incubated with anti-phospho ER $\alpha$ (Ser118), anti-ER $\alpha$, anti-phospho Akt (Thr308), anti-Akt, and anti-phospho ERK1/ERK2 (Thr202/Tyr204), anti-ERK1/ERK2 (Cell signaling, USA) antibodies for $16 \mathrm{~h}$ at $4^{\circ} \mathrm{C}$. After washing with TBS-T $(0.05 \%)$, the blots were incubated with horseradish peroxidase-conjugated anti-rabbit or anti-mouse IgG, and the bands were visualized using the ECL system (Pierce Biotechnology, Rockford, IL, USA). Band images were obtained by using a Molecular Imager ChemiDoc $\mathrm{XRS}^{+}$(Bio-Rad, Hercules, CA, USA) and band intensity was analyzed using Image $\mathrm{Lab}^{\mathrm{TM}}$ software version 2.0.1 (Bio-Rad).

\section{Experimental animals}

Protocols for animal use were reviewed and approved by the Institutional Animal Care and Use Committee at the Dongguk University Ilsan Hospital (No. 2010-0530) and were in accordance with National Institute of Health guidelines. Healthy Wistar strain albino female rats (200-250 g, 8 weeks old) were obtained from OrientBio (Seoul, Korea) and were allowed 1 week for quarantine and acclimatization. Animals were housed under conditions of constant temperature $\left(22 \pm 1^{\circ} \mathrm{C}\right)$, relative humidity $(55 \pm 1 \%)$ and $12 \mathrm{~h}$ light/ $12 \mathrm{~h}$ dark cycle (light on at 7:00 am). They were housed in polycarbonate cages and given tap water and commercial rodent chow (Samyang Feed, Daejeon, Korea) ad libitum. The rats were blindly randomized into four groups, each group containing ten rats: sham operated group (Sham), saline treated ovariectomized group (OVX), Sutaehwan-Gami treated group (SG) and raloxifene treated group (RLX). We provided the animals with SG at a dose of $500 \mathrm{mg} / \mathrm{kg}$ bw/day and RLX at a dose of $5.4 \mathrm{mg} / \mathrm{kg}$ bw/day with standard rat pellets for 3 months. In the sham group, rats were operated but the ovaries were not removed. Treatment started 1 week after bilateral ovariectomy under anesthesia with 3\% sodium pentobarbital. One day after 3 month treatment, the rats were anesthetized with i.p. injection of Rompun $(0.04 \mathrm{ml} /$ $100 \mathrm{~g})$ and Zoletil $(0.04 \mathrm{ml} / 100 \mathrm{~g})$. The animals were quickly dissected and cardiac blood, ovaries and uteri were collected for further analyses. Blood samples were allowed to clot at room temperature and the serum was separated by centrifuging at $400 \mathrm{~g}$ for $15 \mathrm{~min}$. Body weight (BW) was recorded on the last day of the experiment. The uteri were removed and adhering fats were trimmed away. The uterine index (UI, \%) was calculated by dividing the uterine weight by body weight. All specimens and serum samples were stored at $-80^{\circ} \mathrm{C}$ until used for further assays.

\section{Laboratory measurement}

Serum concentrations of total cholesterol (TC), high density lipoprotein (HDL) cholesterol, triglyceride (TG), glucose, glutamic oxaloacetic transaminase (GOT), glutamic pyruvic transaminase (GPT) were measured by enzymatic methods using commercial assay kit (Asan Pharm., Seoul, Korea). The calcium (Ca) and phosphorus (P) levels were measured by colorimetric assay kits (Biovision, USA). Alkaline phosphatase (ALP) and estradiol-17 $\beta \quad\left(E_{2} \beta\right)$ concentrations were determined using the BioVision assay kit (BioVision, USA) and Assay Design EIA kit (Assay Design, Ann Arbor, MI, USA), respectively. Nitric oxide (NO) is rapidly oxidized to nitrite and nitrate, which can be used to determine NO production. Nitric oxide colorimetric assay kit (Biovision, USA) was used to measure the total nitrate/nitrite in the samples. Measurement was carried out according to manufacturer protocol.

\section{Histological analysis}

Uterine tissue specimens were fixed in $10 \%$ formalin for at least $24 \mathrm{~h}$ at room temperature. After fixation, tissues were dehydrated in graded ethanol, cleared in xylene, and embedded in paraffin. Thin sections $(4 \mu \mathrm{m})$ were mounted on glass slides, dewaxed, rehydrated to distilled water, and stained with hematoxylin, and eosin. As part of the histological evaluation, all slides were examined by a pathologist, without knowledge of the previous treatment, under a light microscope.

\section{Data analysis}

Results were given as mean \pm S.E. or mean \pm S.D. Data were analyzed using one-way analysis of variance (ANOVA) followed by Tukey's post hoc test for multiple comparisons where appropriate. A p-value of 0.05 or less was considered as indicative of a significant difference.

\section{Results}

\section{Effect of SG on cell viability}

The potential cytotoxic effect of SG was investigated by determining its effect on the viability of a human breast adenocarcinoma cell line, MCF-7 cells. Cells were treated with SG at concentrations of 0.01, 0.1, 1.0, 5.0 and $10.0 \mu \mathrm{g} / \mathrm{ml}$. After $48 \mathrm{~h} \mathrm{SG}$ treatment, cell death was examined by MTT assay. SG showed no significant cytotoxicity by $5 \mu \mathrm{g} / \mathrm{ml}$ of SG but treatment with the highest dose $(10.0 \mu \mathrm{g} / \mathrm{ml})$ of SG reduced cell viability by $74.51 \pm$ 7.1\% (Figure 1). 


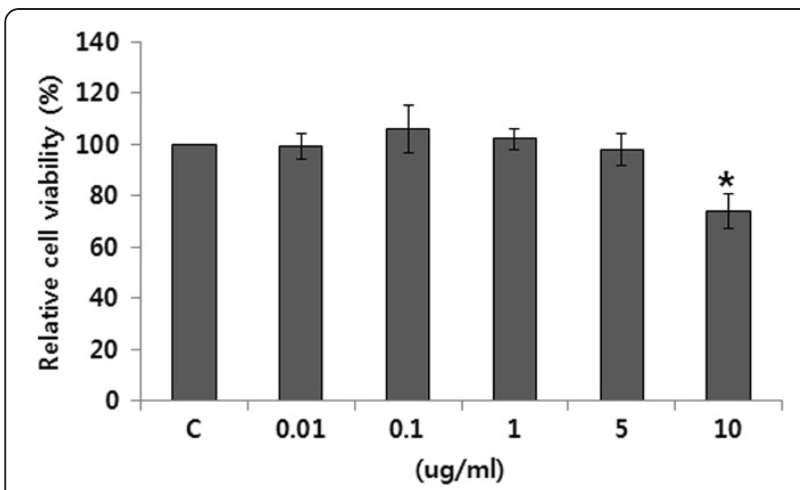

Figure 1 Effect of SG on cell viability. MCF-7 cells were treated with different concentrations of SG for 48 hours. Cell viability was determined by MTT assay. Data are mean \pm SE of three experiments performed in triplicate. ${ }^{*} P<0.05$ versus $0 \mu \mathrm{g} / \mathrm{ml}$.

\section{Effect of SG on phosphorylation of ERa/ERK/Akt in MCF-7 cells}

In order to examine the estrogenic effect of SG, we measured phosphor-ER $\alpha$ and total-ER $\alpha$ from MCF-7 cells human breast adenocarcinoma cells in the presence of $1 \mu \mathrm{g} / \mathrm{ml} \mathrm{SG}$ after different time durations. As shown in Figure 2, SG treatment led to an increased phosphorylation of ER $\alpha$ into the medium, which reached maximum at $120 \mathrm{~min}$. Since phosphorylation of ER $\alpha$ occurs through the action of second messenger signaling pathways, the phosphorylation levels of ERK and Akt were measured. A dose of $1 \mu \mathrm{g} / \mathrm{ml} \mathrm{SG}$ induced a rapid, 2-fold increase in the phosphorylation state of ERK at $5 \mathrm{~min}$ and then gradually increased to $60 \mathrm{~min}$. Akt phosphorylation reached a maximum level at $30 \mathrm{~min}$ of SG treatment and this relatively high level of phosphorylation was maintained up to 2 hours.

\section{Body weight and uterine index in ovariectomized rats} The body weights of the ovariectomized and sham rats were not significantly different at the start of the study (data not shown). After three months, placebo-treated OVX rats weighed $22.4 \%$ more than sham rats $(\mathrm{P}<0.05)$ despite a similar food intake (Table 2). Treatment with raloxifene but not with SG prevented the ovariectomyinduced weight gain $(\mathrm{P}<0.05$, versus $\mathrm{OVX})$. Uterine index was significantly reduced in the OVX group $(\mathrm{P}<0.01$, versus sham group). Treatment of ovariectomized rats with either SG or raloxifene increased the uterine index compared with the OVX group, though not significantly.

\section{Serum biochemical markers in ovariectomized rats}

The effects of SG on serum biochemical markers are summarized in Table 2. OVX rats showed significant increase of TC ( $P<0.01$, versus sham group), but raloxifene prevented ovariectomy-induced increase in $\mathrm{TC}(\mathrm{P}<$ 0.05 , versus OVX). Treatment with either SG or raloxifene significantly reduced the serum TG compared to the saline-treated OVX group. Ovariectomy appears to increase serum ALP, Ca and P levels, but these changes did not reach statistical significance. However, treatment of ovariectomized rats with raloxifene significantly altered serum $\mathrm{Ca}(\mathrm{P}<0.05$, versus OVX). The effects of $\mathrm{SG}$ on liver were determined by the measurement of serum GOT and GPT levels. The OVX group exhibited an elevation in serum levels of GOT and GPT, indicating liver injury. Decreases in the levels of GOT and GPT were observed in the $\mathrm{SG}$ and raloxifene groups $(\mathrm{P}<$ 0.05 , versus $\mathrm{OVX})$. As expected, the significantly reduced $\mathrm{E}_{2} \beta$ level in saline-treated ovariectomized rats $(\mathrm{P}<0.01$, versus sham group) was raised by treatment with either SG or raloxifene ( $\mathrm{P}<0.05$, versus OVX). NO appears to be low with the treatment with either SG or raloxifene.

\section{Effect of SG on phosphorylation of ERK and Akt in the uterus of ovariectomized rats}

Our study showed that ovariectomy led to an increase of phosphorylation of ERK. To investigate the long-term effect of a herbal mixture with estrogen-like properties on
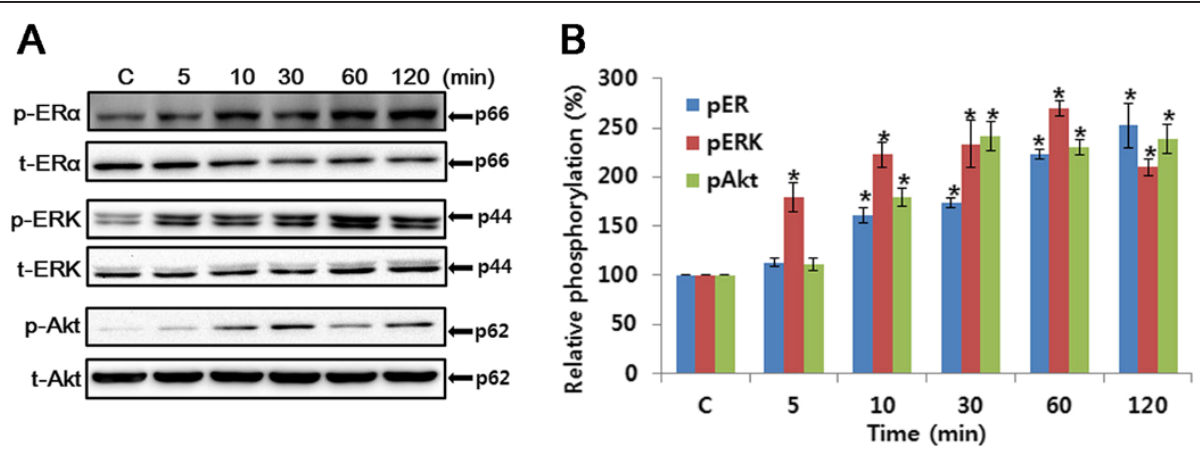

Figure 2 Effect of SG on the activation of ERa, ERK and Akt in the MCF-7 cells. Total and phosphorylation state of each protein was measured in MCF-7 cells which were treated with SG at $1 \mu \mathrm{g} / \mathrm{ml}$ for the indicated time. The whole cell lysates were immunoblotted with anti-p- ERa/ERK/Akt or ERa/ERK/Akt antibody. The intensity of the phosphorylated or total ERa/ERK/Akt was quantified by densitometry, and the intensity of the phosphorylated ERa/ERK/Akt band was normalized to that of total ERa/ERK/Akt. ${ }^{*} P<0.05$ versus control. 
Table 2 Effects of SG on serum biochemical markers, body weight and uterine index in ovariectomized rats

\begin{tabular}{|c|c|c|c|c|c|c|c|c|c|c|c|c|c|}
\hline iroup & $\begin{array}{c}\mathrm{TC} \\
(\mathrm{mg} / \\
\mathrm{ml})\end{array}$ & $\begin{array}{c}\mathrm{HDL} \\
(\mathrm{mg} / \\
\mathrm{ml})\end{array}$ & $\begin{array}{c}\mathrm{TG} \\
(\mathrm{mg} / \\
\mathrm{ml})\end{array}$ & $\begin{array}{c}\text { Gluc } \\
\text { (mg/ } \\
\mathrm{ml})\end{array}$ & $\begin{array}{c}\text { GOT } \\
\text { (Karmen/ } \\
\text { ml) }\end{array}$ & $\begin{array}{c}\text { GPT } \\
\text { (Karmen/ } \\
\text { ml) }\end{array}$ & $\begin{array}{c}\mathrm{Ca}(\mu \mathrm{g} / \\
\mathrm{ml})\end{array}$ & $\begin{array}{c}\mathrm{P} \\
(\mathrm{nmol} / \\
\mathrm{ml})\end{array}$ & $\begin{array}{c}\text { ALP } \\
(\mu \mathrm{mol} / \\
\mathrm{ml})\end{array}$ & $\begin{array}{c}\mathrm{E} 2 \beta(\mathrm{pg} / \\
\mathrm{ml})\end{array}$ & $\begin{array}{c}\mathrm{NO} \\
(\mathrm{mM} / \\
\mathrm{ml})\end{array}$ & BW (g) & UI (\%) \\
\hline ham & $\begin{array}{c}0.59 \pm \\
0.01\end{array}$ & $\begin{array}{c}0.20 \pm \\
0.02\end{array}$ & & & & & & & & & & & $\begin{array}{c}0.16 \\
\pm 0.02\end{array}$ \\
\hline DVX & & $\begin{array}{c}0.23 \pm \\
0.01\end{array}$ & $\begin{array}{c}1.04 \pm \\
0.14\end{array}$ & $\begin{array}{c}2.55 \pm \\
0.19\end{array}$ & $\begin{array}{c}77.32 \pm \\
4.66\end{array}$ & & & & & & & & \\
\hline (3) & $\begin{array}{c}1.08 \pm \\
0.07\end{array}$ & $\begin{array}{c}0.27 \pm \\
0.02\end{array}$ & $\begin{array}{l}0.41 \pm \\
0.08+\end{array}$ & $\begin{array}{c}3.16 \pm \\
0.21\end{array}$ & $\begin{array}{c}52.15 \pm \\
2.42 \dagger\end{array}$ & $\begin{array}{l}8.74 \pm \\
2.69+\end{array}$ & $\begin{array}{c}1.16 \pm \\
0.07\end{array}$ & $\begin{array}{l}7.16 \pm \\
0.05\end{array}$ & $\begin{array}{c}38.21 \pm \\
6.72\end{array}$ & & $\begin{array}{c}4.18 \pm \\
0.32\end{array}$ & & $\begin{array}{c}0.08 \pm \\
0.08\end{array}$ \\
\hline LX & $\begin{array}{c}0.67 \pm \\
0.04 \dagger\end{array}$ & $\begin{array}{c}0.27 \pm \\
0.05\end{array}$ & & $\begin{array}{c}3.37 \pm \\
0.19\end{array}$ & $\begin{array}{c}53.39 \pm \\
3.99+\end{array}$ & $\begin{array}{c}11.34 \pm \\
1.63 \dagger\end{array}$ & $\begin{array}{l}1.05 \pm \\
0.10 \dagger\end{array}$ & $\begin{array}{c}7.24 \pm \\
0.08\end{array}$ & $\begin{array}{c}42.68 \pm \\
10.28\end{array}$ & & $\begin{array}{c}3.11 \pm \\
0.28\end{array}$ & & $\begin{array}{c}0.07 \pm \\
0.01\end{array}$ \\
\hline
\end{tabular}

Mean \pm S.D. ${ }^{* *} \mathrm{P}<0.01,{ }^{*} \mathrm{P}<0.05$ vs sham, ${ }^{\mathrm{t}} \mathrm{P}<0.01,{ }^{\dagger} \mathrm{P}<0.05$ vs OVX.

activation of ERK and Akt in vivo, we treated ovariectomized rats with SG for 3 months. It was found that SG and raloxifene increased the phosphorylation levels of ERK and Akt in the uterus (Figure 3).

\section{Uterine morphology in ovariectomized rats}

Under light microscopy, a marked atrophy of the uterus was observed in ovariectomized rats that was about half the size of that in sham rats (Figure 4). Even though our study did not measure the uterine histologic parameters, this finding might be due to decreased epithelial cell height and myometrial thickness. A partial reversal of uterine atrophy was seen in ovariectomized rats treated with either SG or raloxifene, probably due to an increase in the amount of collagen in the stroma.

\section{Discussion}

Ovariectomy is a standard surgical procedure to induce menopause in experimental animals and ovariectomized female rats show a dramatic cessation of ovarian function and higher risk of osteoporosis [17]. Our study showed that those rats which were ovariectomized and not treated with either SG or raloxifene showed a significant decrease in uterine weight compared to those rats which underwent only sham operation. The reduction of uterine weight was due to an atrophy of endometrium resulting from a lack of hormones secreted by the ovaries. Black et al. [18] have described further evidence of reduced uterine weight by the reduction of uterine epithelial height, uterine myometrial thickness and uterine stromal expansion. Recent data show that ovariectomy also caused atrophy of the vaginal epithelium in rats [19]. However the administration of SG to ovariectomized rats for three months appeared to increase the weight of the uterus, mainly due to lack of uterine atrophy compared to the placebo-treated ovariectomized rats. This improvement in uterine atrophy is probably due to the presence of biologically active phytoestrogenlike molecules in SG. It is interesting to note that the insignificant change of uterine weight in raloxifene-treated ovariectomized rats seen in our study confirms the fact that raloxifene lacks uterotrophic activity due to its antiestrogenic properties in the uterus [18].

Our study showed ovariectomized rats significantly increased body weight, which was also observed in other studies $[19,20]$. The effect of estrogen insufficiency on lipid metabolism during the menopause has been well documented since postmenopausal women receiving estrogen replacement therapy have been found not to display the characteristic pattern of body weight and BMI
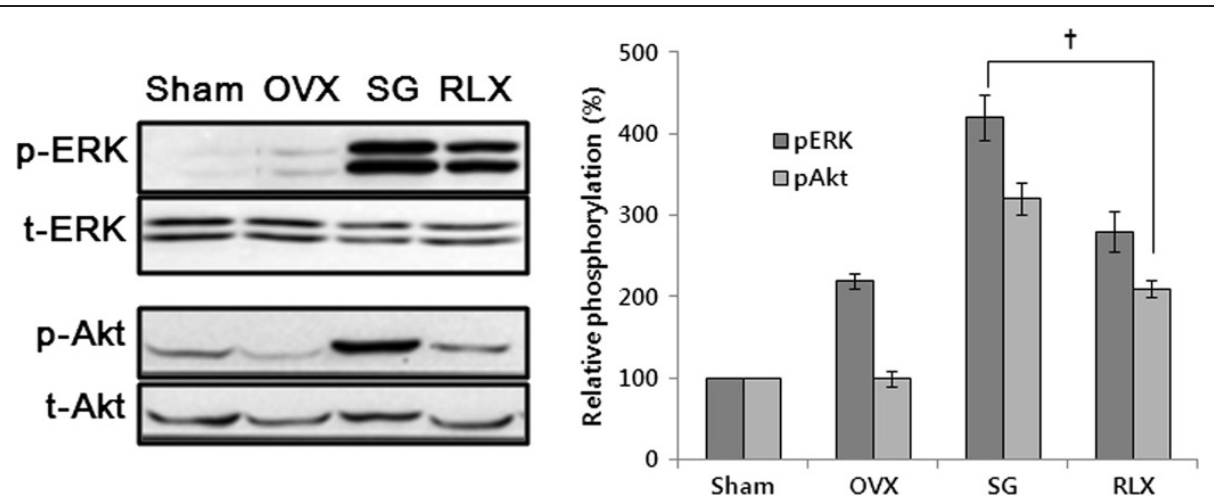

Figure 3 Effect of SG on the activation of ERK and Akt. Ovariectomized rats were treated with SG or raloxifene for 3 months. The uterine tissue lysates were immunoblotted with anti-p-ERK, anti p-Akt, ERK antibody and Akt antibody. The intensity of protein was quantified by densitometry and the intensity of the phosphorylated ERK or Akt band was normalized to that of total ERK or total Akt, respectively. $+P<0.05$ versus OVX. 

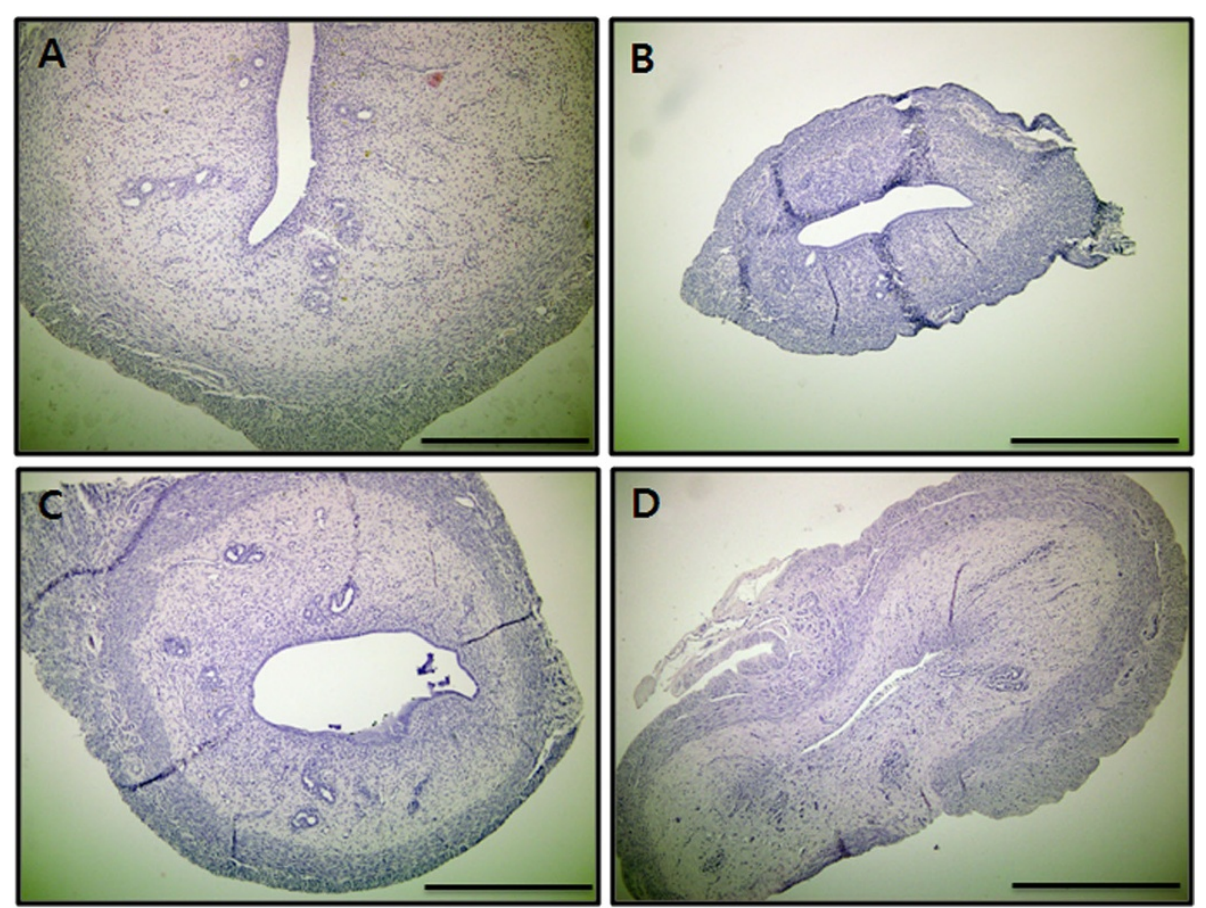

Figure 4 Effect of SG on uterine morphology in ovariectomized rats. Following three month treatment, animals were sacrificed and uterus was removed. Formalin-fixed rat uteri were paraffin-sectioned serially into $4 \mu \mathrm{m}$ sections to be stained with hematoxylin and eosin. A: Sham, B: OVX, C: SG, D: RLX, Bar $=500 \mu \mathrm{m}$.

increase including a shift to a central android fat distribution associated with menopause [21-23]. Furthermore, aromatase-knockout mice displayed progressive accumulation of intra-abdominal adipose tissue compared with wild type counterparts in both males and females [24,25] demonstrating an important role for estrogen in the maintenance of lipid homeostasis. It is thus possible that some of the phytoestrogen-like molecules in SG were involved in the regulation of lipid metabolism although the prevention of ovariectomy-induced weight gain by SG was not significant. The magnitude of the lipid metabolism effect of raloxifene was more distinguishable than that of SG.

The serum biochemical profiles in our SG- or raloxifene-treated rats showed mixed findings. SG and raloxifene both produced a marked reduction in serum triglyceride concentrations. Since the administration of estrogen to postmenopausal women increased triglyceride levels [26] and changes in triglyceride levels were negatively associated with changes in estradiol levels in premenopausal women [27], it follows that changes in triglyceride concentrations in our study must be related with changes in body weight. A trend to a progressive increase in body weight during menopausal transition is closely associated with an increase in total cholesterol and LDL cholesterol levels, and no change in HDL cholesterol levels [27]. Our ovariectomized rats showed no significant change in HDL concentrations. Thus loss of female steroid hormone alone did not influence HDL cholesterol level. While the hypocholesterolemic effect of raloxifene was obvious, SG showed minimal lowering of cholesterol.

Another characteristic of menopausal symptoms is bone loss. The measurement of ALP activity can be used as a barometer of bone formation and bone resorption in vivo. It is common to see an increase in serum ALP activity and subsequent DPD (deoxypyridinoline, a breakdown product of collagen during bone resorption) level in response to ovariectomy [28]. Our results indicate that treatment with SG did not lower serum ALP activity, suggesting that SG might not have enough potent phytoestrogen-like molecules to affect the bone turnover rate in rats.

Menopause is further associated with increased oxidative stress and metabolic disorders which can cause several age-related diseases [17]. In fact, estrogen has potent antioxidant effects and can reduce risk factors for general cardiovascular diseases by reducing inflammation [29]. Behr et al. [17] confirmed that ovariectomized rats presented increased plasma oxidative stress. NO controls the vascular tone and blood flow by activating soluble guanylate cyclase in the vascular smooth muscles. Abnormalities in vascular NO production thus result in endothelial dysfunction [30]. The discrepancy between $\mathrm{NO}$ and estradiol 
profiles from SG administration implies that the estrogenic effects of SG may not be mediated by an increase production of NO in our study. Different oxidative damage parameters need to be analyzed by further studies to clarify this discrepancy. It is true that the measurement of $\mathrm{NO}$ is problematic due to its short half-life $(\sim 5 \mathrm{~s})$ and its high reactivity with other biological components [31].

Phosphorylation of ER $\alpha$ is enhanced in response to estrogen binding and through the action of second messenger signaling pathway [32]. ERK and Akt are serine/ threonine protein kinase, which plays a major role in mitogenic signaling. Here we report that SG-induced $\mathrm{ER} \alpha$ phosphorylation occurs within minutes. The in vitro phosphorylation pattern of ERK and Akt was similar to that of ER $\alpha$. In our in vivo data, rat uterus under the influence of SG similarly mediated the phosphorylation of ERK and Akt. These results lead to a model in which the posttranslational modification of protein kinase cascades is the result of a transcription-independent and nongenomic action of estrogen receptor.

\section{Conclusion}

In conclusion, SG as a dried decoction consisting of six herbal medicines was proven to have phytoestrogen-like properties in female ovariectomized rats. The data presented here increase our knowledge about the protective and beneficial mechanisms of SG for menopausal symptoms, and it may therefore be a viable candidate compound for the development of therapeutic drugs for the management of menopausal symptoms.

\section{Abbreviations \\ SG: Sutaehwan-gami; DPD: Deoxypyridinoline; TC: Total cholesterol; HDL: High density lipoprotein; TG: Triglyceride; GOT: Glutamic oxaloacetic transaminase; GPT: Glutamic pyruvic transaminase; ALP: Alkaline phosphatase; $\mathrm{E}_{2} \beta$ : Estradiol-17 $\beta$; BMI: Body mass index.}

\section{Competing interest}

All authors manifest that there is no conflict of interests.

\section{Authors' contributions}

SB carried out the animal experiments, namely ovariectomy and dissection of uterus. SH carried out in vitro cellular experiments and immunoblotting. SC participated in the design of the study and performed the statistical analysis and wrote the draft manuscript. MS carried out the revised experiment in MCF-7 cells. DI conceived of the study, and participated in its design and coordination. All authors read and approved the final manuscript.

\section{Acknowledgments}

This work was supported by the 2012 Dongguk University Research Fund.

\section{Author details}

'Department of Obstetrics \& Gynecology, College of Traditional Korean Medicine, Dongguk University, Gyeongju, Republic of Korea. ${ }^{2}$ School of Biomedical Sciences, Charles Sturt University, Bathurst, NSW 2795, Australia. ${ }^{3}$ SungSung Traditional Korean Medicine Clinic, Yongdam-ro 115, Yeonsu-gu, Incheon 406-818, Republic of Korea. ${ }^{4}$ Dongguk University Research Institute of Biotechnology, Dongguk University, 27-3, Phildong 3, Joong-gu, Seoul, Korea 100-715.

Received: 17 April 2012 Accepted: 30 October 2012

Published: 23 November 2012

\section{References}

1. Doyle BJ, Frasor J, Bellows LE, Locklear TD, Perez A, Gomez-Laurito J, Mahady GB: Estrogenic effects of herbal medicines from Costa Rica used for the management of menopausal symptoms. Menopause 2009, 16(4):748-755

2. Burger HG, Dudley EC, Robertson DM, Dennerstein L: Hormonal changes in the menopause transition. Recent Prog Horm Res 2002, 57:257-275.

3. Roepke TA, Ronnekleiv OK, Kelly MJ: Physiological consequences of membrane-initiated estrogen signaling in the brain. Front Biosci 2011, 16:1560-1573.

4. Kato $\mathrm{S}$, Endoh H, Masuhiro Y, Kitamoto T, Uchiyama S, Sasaki H, Masushige S, Gotoh Y, Nishida E, Kawashima H, Metzger D, Chambon P: Activation of the estrogen receptor through phosphorylation by mitogen-activated protein kinase. Science 1995, 270:1491-1494.

5. Nedrow A, Miller J, Walker M, Nygren P, Huffman LH, Nelson HD: Complementary and alternative therapies for the management of menopause-related symptoms: a systematic evidence review. Arch Intern Med 2006, 166:1453-1465.

6. Hulley S, Furberg C, Barrett-Connor E, Cauley J, Grady D, Haskell W, Knopp R, Lowery M, Satterfield S, Schrott H, Vittinghoff E, Hunninghake D, HERS Research Group: Noncardiovascular disease outcomes during 6.8 years of hormone therapy: Heart and Estrogen/progestin Replacement Study follow-up (HERS II). JAMA 2002, 288:58-66.

7. Furness S, Roberts H, Marjoribanks J, Lethaby A, Hickey M, Farquhar C: Hormone therapy in postmenopausal women and risk of endometrial hyperplasia. Cochrane Database Syst Rev 2009, 15:CD000402.

8. Xu L, Zhang S, Sun Z: The traditional Chinese medicine characteristics of etiology and pathogenesis of menopausal syndrome. J Tradit Chin Med 2008, 49:1031-1033.

9. Cho HY: Oriental Medicine: A Modern Interpretation. Compton, CA: Yuin University Press; 1996.

10. Qin DN, She BR, She YC, Wang JH: Effects of flavonoids from Semen Cuscutae on the reproductive system in male rats. Asian J Androl 2000, 2:99-102.

11. Zhao PW, Wang DW, Niu JZ, Wang JF, Wang LQ: Evaluation on phytoestrogen effects of ten kinds of Chinese medicine including flos carthami. Zhongguo Zhong Yao Za Zhi 2007, 32:436-439.

12. Liu ZG, Zhang R, Li C, Ma X, Liu L, Wang JP, Mei QB: The osteoprotective effect of Radix Dipsaci extract in ovariectomized rats. J Ethnopharmacol 2009, 123:74-81.

13. Hewitt KN, Boon WC, Murata Y, Jones ME, Simpson ER: The aromatase knockout mouse presents with a sexually dimorphic disruption to cholesterol homeostasis. Endocrinology 2003, 144:3895-3903.

14. Wang T, Choi RC, Li J, Li J, Bi CW, Zang L, Liu Z, Dong TT, Bi K, Tsim KW: Antihyperlipidemic effect of protodioscin, an active ingredient isolated from the rhizomes of Dioscorea nipponica. Planta Med 2010, 76:1642-1646.

15. Song MY, Lv N, Kim EK, Kwon KS, Yoo YB, Kim JH, Lee SW, Song JH, Lee JH, Lee SK, Shin BC, Ryu DG, Park BH, Kwon KB: Antiobesity activity of aqueous extracts of Rhizoma Dioscoreae Tokoronis on high-fat dietinduced obesity in mice. J Med Food 2009, 12:304-309.

16. Yang Q, Liang RX, Ye JX, Wang L, Yang B, Fu MH, Huang LQ: Experimental study on function of decreasing blood-lipid in hyperlipidemia rats and safety by extract of Flos Carthami. Zhong Guo Shi Yan Fang Ji Xue Za Zhi 2007, 13:30-33.

17. Behr GA, Schnorr CE, Moreira JC: Increased blood oxidative stress in experimental menopause rat model: the effects of vitamin A low-dose supplementation upon antioxidant status in bilateral ovariectomized rats. Fundam Clin Pharmacol 2012, 26(2):235-249.

18. Black LJ, Sato M, Rowley ER, Magee DE, Bekele A, Williams DC, Cullinan GJ Bendele R, Kauffman RF, Bensch WR: Raloxifene (LY139481 HCl) prevents bone loss and reduces serum cholesterol without causing uterine hypertrophy in ovariectomized rats. J Clin Invest 1994, 93:63-69.

19. Zaid SS, Sulaiman SA, Sirajudeen KN, Othman NH: The effects of Tualang honey on female reproductive organs, tibia bone and hormonal profile in ovariectomised rats-animal model for menopause. BMC Complement Altern Med 2010, 10:82.

20. Mori-Okamoto J, Otawara-Hamamoto Y, Yamato H, Yoshimura H: Pomegranate extract improves a depressive state and bone properties in menopausal syndrome model ovariectomized mice. J Ethnopharmacol 2004, 92:93-101. 
21. Gambacciani M, Ciaponi M, Cappagli B, Piaggesi L, De Simone L, Orlandi R, Genazzani AR: Body weight, body fat distribution, and hormonal replacement therapy in early postmenopausal women. J Clin Endocrinol Metab 1997, 82:414-417.

22. Gambacciani M, Ciaponi M, Cappagli B, De Simone L, Orlandi R, Genazzani AR: Prospective evaluation of body weight and body fat distribution in early postmenopausal women with and without hormonal replacement therapy. Maturitas 2001, 39:125-132.

23. Genazzani AR, Gambacciani M: Effect of climacteric transition and hormone replacement therapy on body weight and body fat distribution. Gynecol Endocrinol 2006, 22:145-150.

24. Jones ME, Thorburn AW, Britt KL, Hewitt KN, Wreford NG, Proietto J, Oz OK Leury BJ, Robertson KM, Yao S, Simpson ER: Aromatase-deficient (ArKO) mice have a phenotype of increased adiposity. Proc Natl Acad Sci USA 2000, 97:12735-12740.

25. Jones ME, Thorburn AW, Britt KL, Hewitt KN, Misso ML, Wreford NG, Proietto J, Oz OK, Leury BJ, Robertson KM, Yao S, Simpson ER: Aromatase-deficient (ArKO) mice accumulate excess adipose tissue. I Steroid Biochem Mol Biol 2001, 79:3-9.

26. Kim CJ, Min YK, Ryu WS, Kwak JW, Ryoo UH: Effect of hormone replacement therapy on lipoprotein(a) and lipid levels in postmenopausal women. Influence of various progestogens and duration of therapy. Arch Intern Med 1996, 156:1693-1700.

27. Cho EJ, Min YJ, Oh MS, Kwon JE, Kim JE, Lee WS, Lee KJ, Kim SW, Kim TH, Kim MA, Kim CJ, Ryu WS: Effects of the transition from premenopause to postmenopause on lipids and lipoproteins: quantification and related parameters. Korean I Intern Med 2011, 26:47-53.

28. Xie F, Wu CF, Lai WP, Yang XJ, Cheung PY, Yao XS, Leung PC, Wong MS: The osteoprotective effect of Herba epimedii (HEP) extract in vivo and in vitro. Evid Based Complement Alternat Med 2005, 2:353-361.

29. Stice JP, Lee JS, Pechenino AS, Knowlton AA: Estrogen, aging and the cardiovascular system. Future Cardiol 2009, 5:93-103.

30. Poniedziałek-Czajkowska E, Marciniak B, Kimber-Trojnar Z, LeszczyńskaGorzelak B, Oleszczuk J: Nitric oxide in normal and preeclamptic pregnancy. Curr Pharm Biotechnol 2011, 12:743-749.

31. Serpe MJ, Zhang $X$ : The principles, development and application of microelectrodes for the in vivo determination of nitric oxide. In Electrochemical Methods for Neuroscience. Edited by Michael AC, Borland LM. Boca Raton (FL): CRC Press; 2007. Chapter 21.

32. Lannigan DA: Estrogen receptor phosphorylation. Steroids 2003, 68:1-9.

doi:10.1186/1472-6882-12-227

Cite this article as: Kim et al:: The effects of Sutaehwan-Gami on menopausal symptoms induced by ovariectomy in rats. BMC

Complementary and Alternative Medicine 2012 12:227.

\section{Submit your next manuscript to BioMed Central and take full advantage of:}

- Convenient online submission

- Thorough peer review

- No space constraints or color figure charges

- Immediate publication on acceptance

- Inclusion in PubMed, CAS, Scopus and Google Scholar

- Research which is freely available for redistribution 